\title{
GAMBARAN DEBRIS INDEKS PADA PASIEN DI RUANGAN WANITA RSUD KABUPATEN FAKFAK PROPINSI PAPUA BARAT
}

\author{
Kastini $^{1)}$, Novarita Mariana Koch ${ }^{2)}$ \\ (1) RSUD Fakfak, Jl. Jend.Sudirman Wagom Kab. Fakfak Propinsi Papua Barat \\ (2) Jurusan Kesehatan Gigi Poltekkes Kemenkes Manado Jl. R.W. Mongisidi Malalayang Manado
}

Email : kastini12@gmail.com

\begin{abstract}
ABSTRAK
Pendahuluan : Kesehatan gigi dan mulut penting bagi kesehatan dan kesejahteraan tubuh secara umum dan sangat mempengaruhi kualitas kehidupan, termasuk fungsi bicara, pengunyahan dan rasa percaya diri. Mengukur kebersihan gigi dan mulut merupakan upaya untuk menetukan keadaan kebersihan gigi dan mulut seseorang. Pada umumnya untuk mengukur kebersihan gigi dan mulut digunakansuatu index. Penelitian ini bertujuan untuk mengetahui gambaran debris indeks pada pasien ruangan wanita RSUD Fakfak Papua Barat. Metode : Jenis penelitian ini adalah metode deskriptif yang dilakukan terhadap 31 sampel. Pengumpulan data diperoleh langsung dari responden melalui format pemeriksaan Debris Indeks.Instrumen penelitian diagnose shet. Analisa data menggunakan distribusi frekuensi. Hasil : Hasil penelitian ini menunjukkan bahwa jumlah responden terbanyak yang memiliki Debris Indeks (DI) baik adalah umur 21-40 tahun dengan jumlah 10 orang dan persentase sebesar 32,25\% sedangkan kategori buruk terbanyak yaitu umur 41 tahun keatas 3 orang (9,69\%). Kesimpulan : Pada rentan umur 21-40 tahun terutama pada wanita sudah melakukan gosok gigi minimal 2x sehari secara teratur namun ada beberapa yang masih memiliki kategori yang buruk karena mengabaikan kebersihan gigi dan mulut.
\end{abstract}

\section{Kata Kunci : Kebersihan Gigi dan Mulut,Debris Indeks, Pasien}

\begin{abstract}
Introduction: Oral and dental health is important for the general health and well-being of the body and greatly affects the quality of life, including the functions of speech, chewing and self-confidence. Measuring dental and oral hygiene is an attempt to determine the condition of a person's oral and dental hygiene. In general, to measure oral hygiene, an index is used. This study aims to determine the debris index description in the female patient room of the Fakfak Hospital, West Papua. Methods: This type of research is a descriptive method which was conducted on 31 samples. Data collection was obtained directly from respondents through the Debris Index examination format. Shet diagnostic research instrument. Data analysis using frequency distribution. Results: The results of this study indicate that the largest number of respondents who have a good Debris Index (DI) are aged 21-40 years with a total of 10 people and a percentage of $32.25 \%$ while the most bad category is those aged 41 years and over 3 people $(9.69 \%)$. Conclusion: Those aged 21-40 years old, especially women, have brushed their teeth at least twice a day regularly, but there are some who still have a bad category because they ignore oral and dental hygiene.
\end{abstract}

Keywords: Oral and Dental Hygiene, Debris Index, Patient 


\section{PENDAHULUAN}

Kesehatan merupakan bagian terpenting dalam kehidupan manusia, sehatsecara jasmani dan rohani. Tidak terkecuali anak-anak setiap orang tua menginginkan anaknya bisa tumbuh dan berkembang secara optimal, hal ini dapat dicapai jika tubuh mereka sehat. Dengan kata lain bahwa kesehatan gigi dan mulut merupakan bagian dari integral dari kesehatan tubuh secara keseluruhan yang tidak dapat dipisahkan dari kesehatan tubuh secara umum. ${ }^{1}$

Kesehatan gigi dan mulut penting bagi kesehatan dan kesejahteraan tubuh secara umum dan sangat mempengaruhi kualitas kehidupan, termasuk fungsi bicara, pengunyahan dan rasa percaya diri. Mengukur kebersihan gigi dan mulut merupakan upaya untuk menetukan keadaan kebersihan gigi dan mulut seseorang. Pada umumnya untuk mengukur kebersihan gigi dan mulut digunakan suatu index. Debris indeks merupakan indeks yang digunakan untuk bahan lunak di permukaan gigi berupa plak, material alba, dan food debris. Cara pemeriksaan debris dapat dilakukan dengan menggunakan larutan disklosing ataupun tanpa menggunakan larutan disclosing. Menurut Greene dan Vermillion, kriteria penilaian debris dan kalkulus sama, yaitu mengikuti ketentuan sebagai berikut Menurut Greene dan Vermillion, kriteria penilaian debris dan kalkulus sama, yaitu mengikuti ketentuan yaitu : Baik Jika nilainya antara 0,0-0,6 Sedang : Jika nilainya antara 0,7-1,8, Buruk: Jika nilainya antara $1,9-3,0 .^{2}$

Hasil penelitian Hermawan, dkk (2015), menunjukkan bahwa indeks debris sebelum dilakukan promosi kesehatan berada pada kategori buruk, dan sesudah dilakukan promosi kesehatan indeks debris berada pada kategori sedang, hasil analisis menunjukkan terdapat perbedaan yang bermakna antara indeks debris sebelum dan sesudah dilakukan promosi kesehatan tentang menyikat gigi. Kebersihan gigi dan mulut harus diperhatikan untuk menunjang kesehatan secara umum. ${ }^{3}$

Kesehatan gigi dan mulut bukan hanya tertuju pada seseorang saja tetapi semua orang. Kebersihan gigi dan mulut yang baik akan menjamin kesehatan pada umumnya. Tujuan penelitian ini adalah untuk mendapatkan gambaran debris indeks pada pasien di ruangan wanita RSUD Fakfak Propinsi Papua Barat.

\section{METODE}

Jenis penelitian ini adalah Penelitian ini adalah penelitian metode deskriptif yang dilakukan terhadap 30 sampel. Pengumpulan data diperoleh langsung dari responden melalui format pemeriksaan Debris Indeks. Instrumen penelitian Format pemeriksaan debris indeks, alat tulis menulis, diagnosa set, nier bekken. Bahan Disclosing solution, cotton pellets, sarung tangan, masker, aquades, lysol

Analisa data menggunakan distribusi frekuensi. Populasi merupakan keseluruhan sumber data yang diperlukan dalam suatu penelitian. Dalam penelitian ini yang menjadi populasi adalah pasien RSUD Fakfak ruangan wanita yang berjumlah pasien 30 Responden.

Sampel Pengambilan sampel menggunakan teknik total sampling yaitu cara pengumpulan sampel secara menyeluruh. Sampel yang digunakan dalam penelitian ini adalah total populasi berjumlah pasien.

\section{HASIL}

\section{Gambaran Umum Lokasi Penelitian}

RSUD Kaimana didirikan tahun 2010 dan diresmikan serta mulai dipungsikan tahun 2013 hingga sekarang kurang lebih enam tahun. RSUD Kaimana yang sementara ini berakreditasi tipe $\mathrm{D}$, yang dipimpin oleh direktur Dr Joulanda Mentang dengan staf yang berjumlah kurang lebih 300 Orang.Bangunan berada dijalan batu putih kilo nol yang bangunan ini berdiri ditanah kurang lebih 400 meter persegi degan beberapa unit bangunan.

2. Gambaran Responden Berdasarkan Umur.

Gambaran karakteristik pasien berdasarkan umur dapat dilihat pada tabel 1 dibawah ini. 
Tabel 1. Tabel Distribusi Frekuensi Berdasarkan Umur

\begin{tabular}{ccc}
\hline Umur & Jumlah & Persentase $(\%)$ \\
\hline $10-20$ thn & 3 & 9,67 \\
$21-40$ thn & 16 & 51,61 \\
$41>$ & 12 & 38,72 \\
\hline Total & 31 & 100 \\
\hline
\end{tabular}

Tabel 1. menunjukan bahwa jumlah responden dengan umur antara 21-40 tahun memiliki jumlah terbanyak dengan jumlah 16 orang $(51,61 \%)$, umur $41>$ dengan jumlah 12 orang $(38,72)$ dan dan umur 10-20 tahun sebanyak 3 orang $(9,67 \%)$.

3. Gambaran Responden Berdasarkan Debris Indeks

Tabel.2 Distribusi Frekuensi berdasarkan Debris Indeks (DI)

\begin{tabular}{lcc}
\hline $\begin{array}{l}\text { Debris Indeks } \\
\text { (DI) }\end{array}$ & Jumlah & $\begin{array}{c}\text { Persentase } \\
(\%)\end{array}$ \\
\hline Baik & 17 & 54,84 \\
Sedang & 8 & 25,80 \\
Buruk & 6 & 19,36 \\
\hline Total & 31 & 100 \\
\hline
\end{tabular}

Tabel.2 menunjukan bahwa jumlah terbanyak dengan Debris Indeks (DI) kategori Baik berjumlah 17 orang dengan persentase sebesar $54,84 \%$ dan Debris Indeks (DI) kategori Sedang berjumlah 8 orang dengan persentase sebesar $25,80 \%$ sedangkan Debris Indeks (DI) kategori buruk berjumlah 6 orang dengan persentase sebesar $19,36 \%$.

4. Gambaran Responden Berdasarkan Umur Degan Debris Indeks (DI)

Tabel Distribusi Frekuensi Berdasarkan Umur Dengan Debris Indeks (DI) dapat dilihat pada tabel 3 dibawah ini :
Tabel 3. Tabel Silang Antara Umur Dengan Debris Indeks (DI)

\begin{tabular}{|c|c|c|c|c|c|c|c|c|}
\hline \multirow{2}{*}{$\begin{array}{l}\text { Umur } \\
\text { (tahun } \\
\text { ) }\end{array}$} & \multicolumn{6}{|c|}{ Debris Indeks (DI) } & \multirow[t]{2}{*}{$\mathrm{N}$} & \multirow[t]{2}{*}{$(\%)$} \\
\hline & Baik & $\%$ & Sedang & $\%$ & $\begin{array}{l}\text { Buru } \\
\mathrm{k}\end{array}$ & $\%$ & & \\
\hline $10-20$ & 2 & 6,45 & - & - & 1 & 3,22 & 3 & 9,67 \\
\hline $21-40$ & 10 & 32,25 & 4 & $\begin{array}{l}12, \\
95\end{array}$ & 2 & 6,45 & 16 & 51,61 \\
\hline $41>$ & 5 & 16,14 & 4 & $\begin{array}{l}12, \\
95\end{array}$ & 3 & 9,69 & 12 & 38,72 \\
\hline Total & 17 & $\begin{array}{l}54,8 \\
4 \\
\end{array}$ & 8 & $\begin{array}{l}25, \\
80\end{array}$ & 6 & $\begin{array}{l}19,3 \\
6\end{array}$ & 31 & 100 \\
\hline
\end{tabular}

Tabel.3 menunjukan bahwa jumlah responden terbanyak yang memiliki Debris Indeks (DI) baik adalah umur 21-40 tahun dengan jumlah 10 orang dan persentase sebesar $32,25 \%$, umur $41>5$ orang dengan persentase $16,14 \%$ sedangkan umur 10-20 tahun berjumlah 2 orang dengan persentase sebesar 6,45\%. Jumlah siswa yang memiliki Debris Indeks (DI) sedang sebanyak 4 orang pada rentan umur 21-40 tahun dan $41>$ dengan persentase sebesar $12,95 \%$ sedangkan. Sementara itu responden dengan kategori buruk yaitu umur 41 tahun keatas 3 orang $(9,69), 21-40$ tahun 2 orang $(6,45)$ dam 10 20 tahun 1 orang $(3,22 \%)$.

\section{PEMBAHASAN}

Kebersihan mulut dalam kesehatan gigi dan mulut sangatlah penting. Beberapa masalah mulut dan gigi dapat terjadi karenanya kurang menjaga kebersihan mulut dan gigi. Tujuan menjaga kesehatan gigi dan mulut adalah menghindari lubang pada gigi karena lubang gigi adalah permasalahan utama yang bisa menjadi pusat infeksi bagi organ lain didalam rongga mulut. ${ }^{4}$

Beberapa masalah kesehatan atau penyakit pada gigi dan mulut dapat terjadi sejak usia bayi hingga lansia. Penyakit tersebut dapat menimbulkan berbagai dampak, mulai dampak yang paling ringan seperti ketidak nyamanan hingga dampak yang berat sepeti tidak bisa makan yang menyebabkan seseorang bisa mengalami gangguan nutrisi, dan terjadinya infeksi yang bisa mengakibatkan penyakitpenyakit lain ditubuh kita. ${ }^{5}$ 
Berdasarkan Tabel 2 dapat dilihat bahwa jumlah responden dengan umur antara 21-40 tahun memiliki jumlah terbanyak dengan jumlah 16 orang $(51,61 \%)$, umur $41>$ dengan jumlah 12 orang $(38,72)$ dan dan umur 10-20 tahun sebanyak 3 orang $(9,67 \%)$. Hal ini disebabkan oleh kebiasaan wanita pada rentan umur 21-40 tahun yang aktif mengkonsumsi makanan berupa camilan tanpa membersihkan gigi setelah mengkonsumsi makanan tersebut.

Penelitian ini sejalan dengan penelitian yang dilakukan oleh Hermawan (2015) mengenai Indeks Debris sebelum dan sesudah dilakukian Promosi Kesehatan tentang menyikat gigi pada murid SD Negri Poigar yang menunjukkan adanya perbedaan bermakna antara indeks Debris sebelum dan sesudah dilakukan promosi kesehataan. Dengan demikian maka perlu dilakukannya promosi kesehatan bagi responden demi mencegah ditemukannya debris indeks dengan kategori sedang maupun buruk terutama pada responden dengan rentan umur 21-40 tahun. Berdasarkan Tabel 3 dapat dilihat bahwa jumlah terbanyak dengan Debris Indeks (DI) kategori Baik berjumlah 17 orang dengan persentase sebesar 54,84\% dan Debris Indeks (DI) kategori Sedang berjumlah 8 orang dengan persentase sebesar 25,80\% sedangkan Debris Indeks (DI) kategori buruk berjumlah 6 orang dengan persentase sebesar 19,36\%. Hal ini dapat disebabkan adanya responden yang mengabaikan pentingnya menyikat gigi $2 x$ sehari untuk gigi yang bersih dan sehat. ${ }^{3}$

Berdasarkan Tabel 4 dapat dilihat bahwa jumlah responden terbanyak yang memiliki Debris Indeks (DI) baik adalah umur 21-40 tahun dengan jumlah 10 orang dan persentase sebesar $32,25 \%$, umur $41>5$ orang dengan persentase $16,14 \%$ sedangkan umur 10-20 tahun berjumlah 2 orang dengan persentase sebesar $6,45 \%$. Jumlah siswa yang memiliki Debris Indeks (DI) sedang sebanyak 4 orang pada rentan umur 21-40 tahun dan $41>$ dengan persentase sebesar $12,95 \%$ sedangkan. Sementara itu responden dengan kategori buruk yaitu umur 41 tahun keatas 3 orang $(9,69 \%), 21-40$ tahun 2 orang $(6,45 \%)$ dam 10-20 tahun 1 orang $(3,22 \%)$.

Penelitian ini sejalan dengan penelitian yang dilakukan oleh I Gede KK, (2013) tentang hubungan pengetahuan kebersihan gigi dan mulut dengan status kebersihan gigi dan mulut pada siswa SMA Negeri 9 Manado dengan hasil yang didapatkan adalah siswa dengan jenis kelamin perempuan memiliki pengetahuan yang baik dan paling banyak memiliki indeks OHI-S dengan kategori baik. Hal ini menunjukkan bahwa jenis kelamin perempuan lebih menjaga kebersihan gigi dan mulutnya dibandingkan laki-laki. ${ }^{6}$

\section{KESIMPULAN}

Berdasarkan hasil dari penelitian dan pembahasan, diketahui bahwa pada rentan umur 21-40 tahun terutama pada wanita sudah melakukan gosok gigi minimal $2 x$ sehari secara teratur namun ada beberapa yang masih memiliki kategori yang buruk karena mengabaikan kebersihan gigi dan mulut.

\section{SARAN}

1. Rumah Sakit diharapkan menyediakan sarana media informasi tentang kesehatan gigi dan mulut yang mendukung peningkatan promosi kesehatan tentang kesehatan gigi dan mulut terutama tentang cara memelihara kesehatan gigi dan mulut

2. Responden disarankan untuk lebih memperhatikan kesehatan gigi dan mulut, kemudian aktif mencari tahu informasi tentang pendidikan kesehatan gigi dan mulut melalui penyuluhan dari tenaga kesehatan gigi, sehingga harapan kedepan lebih meningkatkan pemeliharaan kebersihan gigi dan mulut.

3. Peneliti yang akan melakukan penelitian yang sejenis dengan penelitian ini, alangkah baiknya jika lebih memperhatikan kembali masalah yang ada di lapangan yang dapat mempengaruhi derajat kesehatan gigi dan mulut serta dapat menggunakan variabel dan kuesioner yang tepat.

\section{DAFTAR PUSTAKA}

1. Soebroto, (2009). Apa Yang Tidak Dikatakan Dokter Tentang Kesehatan Gigi Anda. Andi Press, Jogjakarta 
2. Putri H.M, Herijulianti,E, Nurjanah, N. (2009). Ilmu Pencegahan Penyakit Jaringan Keras dan jaringan Pendukung Gigi. EGC, Jakarta.

3. Hermawan. 2015. Indeks Debris Sebelum Dan Sesudah Dilakukan Promosi Kesehatan Tentang Menyikat Gigi Pada Murid SD Negeri Poigar.Jurnal e-GiGi Vol.3 No.2 2015

4. Hidayat, R, Tandiari, A,. (2016). Kesehatan Gigi Dan Mulut Apa Yang Sebaiknya Anda tahu? Ed.1.Andi.Yogyakarta.

5. Pintauli dan Hamada, 2008, Menuju Gigi dan Mulut Sehat, Pencegahan dan Pemeliharaan. USU.Press. Medan

6. I Gede K Y, K. Pandelaki K., Ni Wayan Mariati. 2013. Hubungan Pengetahuan Kebersihan Gigi Dan Mulut Dengan Status Kebersihan Gigi Dan Mulut Pada Siswa Sma Negeri 9 Manado. Jurnal e-Gigi Vol 1 No.2 2013 